\title{
On the Effect of Fiscal Zoning on Land and Housing Values ${ }^{\mathrm{T}}$
}

\author{
Paul N. Courant \\ Department of Economics and Institute of Public Policy Studies, \\ The University of Michigan, Ann Arbor, Michigan 48104
}

Received March 19, 1975

\begin{abstract}
The note is a comment on and extension of "The Effect of Zoning on Land Value," by J. C. Ohls, R. C. Weisberg, and M. J. White. It is suggested that some of the results of that paper are very sensitive to the way in which the market for urban housing and the market for urban land are modeled. In the context of a more general model, it is shown that a major result of that paper, that land values may rise or fall, in a metropolitan area, in response to zoning, still holds, although the mechanism underlying the process is very different in the more gencral model. Furthermore, it is shown that the effect of such a zoning change on housing prices and consumer welfare is unambiguous; the former rises and the latter falls. Finally, it is proved that zoning by a small municipality within a metropolitan area will cause land and housing values to fall.
\end{abstract}

\section{INTRODUCTION AND SUMMARY}

In a recent issue of this journal, James C. Ohls, Richard Chadbourn Weisberg, and Michelle J. White (henceforth to be referred to as OWW) presented a number of results concerning the effects of large-lot zoning on land values [1]. In particular, they found that such zoning, when practiced by an entire urban area, could either raise or lower aggregate values. They also suggested (but did not prove) that the effect of a given municipality's decision to restrict apartment construction would be to lower land values in that community. Both OWW's result and their suggestion are derived from a simple, long-run partial equilibrium model of the market for urban land.

In this note, a simple general equilibrium model is used to investigate the same issues that are raised by the OWW model, and substantially different conclusions are reached. This is not meant to suggest that the OWW model is "wrong" and the model presented here is "right." Rather, it is the purpose of this note to show that partial and general equilibrium approaches will lead

${ }^{1}$ This treatment has benefited greatly from discussions with Daniel L. Rubinfeld and comments by Edwin S. Mills and James C. Ohls. Any awkwardness or errors are the author's alone. 
to different conclusions about the effects of zoning on urban housing markets. The question of which approach is more appropriate is not at issue here.

In particular, it will be shown below that by using a more general (albeit still very simple) long-run model, the following results can be established.

1. The effect of metropolitan wide zoning on land value is indeed ambiguous. However, its effect on aggregate consumer welfare is unambiguously negative, and its effect on the price of housing is unambiguously positive. The effect on land value is ambiguous because the value of land used in the unrestricted (single-family) sector rises, and the value of land used in what would be the restricted (apartment) sector in a nonzoned equilibrium may either rise or fall.

2. The effect of large lot zoning by a particular municipality within a metropolitan area is unambiguous; land and housing values fall. Land values fall because land is diverted to the relatively low-priced sector.

In order to establish these results, it is important to distinguish carefully between the properties of an urban area and the properties of a municipality within an urban area. Although OWW do not formally make such a distinction, I believe that the following assumptions are consistent with their treatment.

1. The population of the metropolitan area is fixed. A zoning ordinance adopted by the entire metropolitan area will be referred to as metropolitan zoning.

2. All nonland factors of production, as well as population, are mobile among municipalities. The municipalities are small so that the behavior of a particular municipality cannot affect prices or total outputs in the metropolitan area as a whole. The twin assumptions of openness and smallness are analogous to the assumption that the municipality is a perfect competitor in the production of housing services. ${ }^{2}$ A zoning ordinance adopted by such a municipality will be referred to as municipal zoning.

In their model, OWW assume that there are separate (although perhaps related) demands for land used in apartment buildings and land used in singlefamily structures. Equilibrium in their model requires that, in the absence of zoning, the prices of land in the two uses be equal. It is further assumed that the total quantity of land used for housing is fixed, both within a municipality and within the metropolitan area. It will be assumed here that the demand for land is derived from the demand for housing service, rather than from individual demands for apartments and single-family dwellings. Further, it will be assumed that equilibrium requires that consumers be in locational equilibrium with respect to each other. From these two assumptions the results outlined above will be derived.

${ }^{2}$ See Polinsky and Rubinfeld [2] for a discussion of the properties of small, open cities. 


\section{METROPOLITAN ZONING IN A CLOSED METROPOLITAN AREA}

Consider a closed metropolitan area with the following characteristics.

1. There is a fixed stock of land $\vec{L}$ to be used for residential purposes.

2. Each parcel of land has associated with it an amenity value, denoted by $Z$. Higher values of $Z$ indicate land with higher amenity values. Amenities, in this context, include public services, proximity to places of work or shopping, neighborhood character, etc. They are assumed to be exogenous to the model, as is the total stock of land. If the amount of land possessing a particular amenity value $Z^{\prime}$ is $L\left(Z^{\prime}\right)$, then

$$
\bar{L}=\int_{\underline{Z}}^{\bar{Z}} L\left(Z^{\prime}\right) d Z^{\prime},
$$

where $\underline{Z}$ is the lowest and $\bar{Z}$ is the highest value of $Z$ in the metropolitan area.

3. There is a production function for housing service, twice differentiable, homogeneous of degree one, and concave in its arguments,

$$
H=H(K, L),
$$

where $K$ represents physical units of capital.

It is assumed that $Z$ does not affect the technological characteristics of the use of land in the production of housing service.

4. All consumers in the metropolitan area are identical. In particular, they all have the same utility function, defined on housing, a composite consumption good, and $Z$. Following Solow [3], and subsuming the price of the consumption good in the functional form, consumers have identical indirect utility functions

$$
V=V(P, Y, Z),
$$

where $P$ is the price of housing, and $Y$ is income. In equilibrium all consumers of the same income attain the same level of utility. For ease of exposition, it is further assumed that all consumers have the same level of income.

5. The rental rate on capital, $r$, is determined in a national capital market, and is exogenous to the model. Thus, with respect to capital the metropolitan area itself is open and small.

6. The markets for housing and residential land are perfectly competitive

Given this simple model of the market for residential land, the propositions concerning the effects of large-lot zoning are established by comparing a solution of the model without zoning to one in which there is large-lot zoning.

Since the production function for housing services is homogeneous of degree one, and denoting housing per unit of land by the variable $h$ and capital 
per unit of land by the variable $k,(2)$ can be rewritten as

$$
H=L \cdot h(k) \text {. }
$$

It is well known [4] that $k$ is a monotone increasing function of the ratio of $R$ to $r$, where $R$ is the rental on land. Since utility decreases in the price of housing and increases in $Z$, and since competitive equilibrium requires that the value of output just cover cost, $R$ and $P$ must increase in $Z$. Thus, the output of housing on land of a given $Z$ is

$$
H(Z)=L(Z) \cdot h\{k[(R / r)(Z)]\},
$$

where $h^{\prime}(k), k^{\prime}(R / r)$, and $R / r^{\prime}(Z)$ are all strictly positive.

Thus, while the OWW condition that land of the same type receive the same rent at all locations is formally correct, if such land is used in the production of housing service with a technology that permits factor substitution, the capital-land ratio is also identical at all locations possessing identical land. Since apartments have high and single family structures low capital to land ratios equilibrium requires that the same type of structure be produced at all locations earning a given rent. In other words, if consumers demand housing services rather than apartments or single-family structures per se, either apartments or single-family houses, but not both, will be provided on land earning a given rent.

The preceding discussion suggests an obvious way to model large-lot zoning. Large-lot zoning is assumed to place a ceiling on the capital-land ratio in the production of housing service. In order to investigate the effects of such a policy, consider two states of the world: a competitive equilibrium in which capital-land ratios are free to vary according to the dictates of the market, and an equilibrium in which the capital-land ratio on at least some land is not permitted to rise above some value $g$. For ease of exposition, consider separately the case in which no land may have a capital intensity greater than $g$ and the case in which only some land is so zoned.

In the competitive equilibrium in which there is no large-lot zoning, the total output of housing is the integral of (5),

$$
\bar{H}=\int_{\underline{Z}}^{\bar{Z}} H(Z) d Z=\int_{\underline{Z}}^{\bar{Z}} L(Z) \cdot h\{k[(R / r)(Z)]\} d Z .
$$

Now consider a competitive equilibrium in which the maximum capital to land ratio is fixed at $g$. Assume that the demand for housing and $Z$ at the given income level and price of the composite good are such that the capital to land ratio employed in the production of housing service at all values of $Z$ greater than some $Z_{g}$ would be greater than $g$ in competetive equilibrium.

Clearly, zoning reduces the production of housing services on land where $Z$ is greater than $Z_{g}$. The amount of capital devoted to housing falls, and the 
amount of land stays constant. If housing is not perfectly substitutable with any good, utility must fall and the price of housing must rise at all locations. A consumer located in a nonzoned part of the metropolitan area can increase his utility only if the price of housing falls. But if the price of housing falls in the nonzoned area, the supply of housing in that area must also fall, as the price of land falls, implying lower capital to land ratios on every unit of land. At a given $Z$, however, a fall in the price of housing induces consumers to purchase more housing. Thus, in order for utility to rise, a fixed number of consumers must be enabled to consume more housing per capita under circumstances where less housing is produced at each location. This is a contradiction. A similar contradiction results if utility remains constant. Thus utility must fall and the price of housing must rise at every location.

The rise in the price of housing in nonzoned locations has the interesting implication that land rent must also rise at those locations. Initially, the price rise leads to an increase in the value of the marginal product of both factors. Land rent rises, along with the capital to land ratio, until the values of the marginal products are in equilibrium with respect to the factor price ratios. Thus, metropolitan zoning of this type has the perverse result of increasing the capital intensity of housing production, as well as total housing supply, in the nonzoned part of the urban area. Because of this, the effects of the zoning change on the aggregate supply of housing, the aggregate value of housing, and the aggregate value of land are ambiguous. All these values rise in the nonzoned sector of the city. In the zoned sector, the values of housing and of land rise or fall depending on functional forms and their parameters. The supply of housing, of course, falls.

We can now easily consider the case where only some land on which $Z$ is greater than $Z_{g}$ is zoned against capital to land ratios exceeding $g$. Consider land at some value of $Z$ greater than $Z_{y}$. Equilibrium among consumers requires that housing provided on such land sell for the same price regardless of the technology used in its production. On nonzoned land, the efficient technology can be freely employed, whereas on zoned land, producers of housing services must use a suboptimal capital to land ratio. Thus, the value of the marginal product of land is higher where the capital to land ratio is free to reach its optimum level; hence, land rent is higher there, as well. For every class of land with $Z$ greater than $Z_{\theta}$, then, the zero profit condition of perfect competition requires that unzoned land receive a higher rent than zoned land. All of the other results discussed above still hold.

\section{MUNICIPAL ZONING IN AN OPEN MUNICIPALITY}

The openness and smallness of municipalities require that the price of housing at each $Z$ be the same in all municipalities of a metropolitan area, since the population is perfectly mobile across municipalities, all consumers must have equal utility, and all consumers are assumed to earn the same wage. 
Consider a municipality located in a metropolitan area in which some zoning already exists. At each $Z$ there is a unique $P(Z)$ in equilibrium. In addition, at each $Z$ greater than $Z_{g}$, there are two land rents, $R_{f}(Z)$, the land rent in unrestricted areas, and $R_{z}(Z)$, the land rent in zoned areas. It was shown above that $R_{f}(Z)$ is greater than $R_{z}(Z)$ for any $Z$ greater than $Z_{y}$. Assume that the municipality in question has not yet practiced any zoning. For simplicity of exposition, assume further that all land in the municipality has the same $Z$, which is greater than $Z_{g}$. The effects of zoning are clear. The land rent at all locations falls from $R_{f}(Z)$ to $R_{z}(Z)$. The production of housing also falls, as less capital is used on the same amount of land. Since the municipality is "competitive" as a producer of housing, prices do not change. However, the value of housing and land must both fall. This does not happen, as in the OWW model, because the supply of land to low-density structures on low-priced land is artificially increased. Rather, it happens because producers of housing services are forced to use inefficient production processes, which reduces the value of the marginal product of the land which they employ. If the municipality has some land with $Z$ less than $Z_{y}$, these results still hold. Rent falls on the zoned land, and there is no change on the unrestricted land. In either event, since the quantity of housing produced falls in the municipality as a whole, and since prices of consumer goods, including housing, do not change, the population of the municipality must fall.

Finally, consider the situation if the municipality were in a metropolitan area in which there were no metropolitan zoning. Then the metropolitan wide market for land would not have established differential rents of $R_{f}$ and $R_{z}$. The only market price of land of a given $Z$ would be $R_{f}(Z)$. The result of a municipal zoning ordinance, then, would be to force producers on zoned land to operate at a loss, as they would be required to use suboptimal capital-land ratios where, at the existing factor prices, only the optimal capital to land ratio would yield profits as high as zero. Thus, if openness and smallness mean that the municipality can have no effect on market-wide prices, municipal zoning would prevent the zoned land from being used to produce housing at all.

\section{CONCLUSION}

Many interesting issues about zoning, some of which are discussed in OWW, have been ignored in this note. What has been accomplished, it is hoped, is some clarification of issues concerning the relationships among land values, the optimality of perfect competition in land markets, and the important differences between open and closed cities as units for the analysis of urban land and housing markets.

In particular, there is nothing in the theory of perfect competition which implies that a competitive market will maximize the money value of a factor of production. (Indeed, it is well known that acreage allotments can increase the value of land in agriculture, because the industry-wide derived demand for 
the factor is highly inelastic.) What perfect competition does maximize is the "average utility product" of all factors of production. Thus, in the closed metropolitan area, the aggregate money value of land may rise or fall in response to zoning, but the amount of utility produced from that land must fall.

In the open municipality however, as in Stull's [5] open city, zoning, in the absence of externalities, unambiguously reduces property values. In this case the value of land is maximized by perfect competition, for the simple reason that all demand and supply functions, with respect to a perfect competitor, are perfectly elastic. In this context, the municipality is a perfect competitor in the production of housing services.

In general, and in this case, the difference between open and closed cities is somewhat analogous to the difference between competitive industries and competitive firms. As in industrial organization, both appropriate questions and correct analysis will be different depending on whether the analysis is of the whole or of a small part.

\section{REFERENCES}

1. James C. Ohls, Richard Chadbourn Weisberg, and Michelle J. White, The effect of zoning on land value, J. Urban Econ. 1, 428-444 (1974).

2. A. Mitchell Polinsky and Daniel L. Rubinfeld, "The Long Run Effects of a Residential Property Tax and Local Public Services," Urban Institute Working Paper \# 1207-29, processed (February 1974).

3. Robert M. Solow, On equilibrium models of urban location, in "Essays in Modern Economics" (Parkin, Ed.), pp. 2-16, Longman, London, (1973).

4. R. G. D. Allen, "Mathematical Analysis for Economists," p. 318, St. Martin's Press, New York (1938).

5. William J. Stull, Land use and zoning in an urban economy, Amer. Econ. Rev. (June 1974), pp. 337-347. 